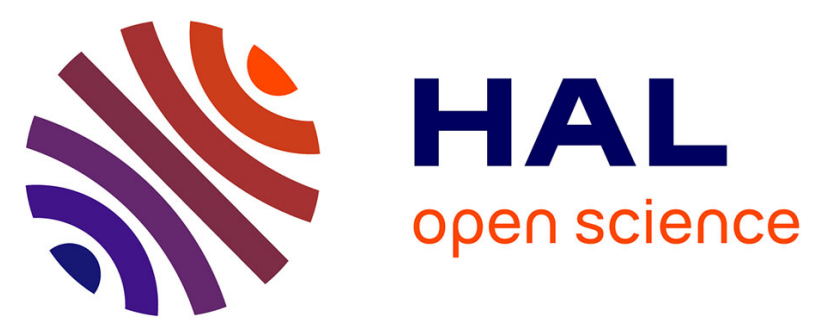

\title{
Plutonium in the environment: key factors related to impact assessment in case of an accidental atmospheric release
}

Philippe Guétat, V. M. Moulin, Pascal E. Reiller, T. Vercouter, L. Lionel Bion, P. Fritsch, M. Monfort, A. Flury-Herard, A. Comte, F. Ménétrier, et al.

\section{To cite this version:}

Philippe Guétat, V. M. Moulin, Pascal E. Reiller, T. Vercouter, L. Lionel Bion, et al.. Plutonium in the environment: key factors related to impact assessment in case of an accidental atmospheric release. Radiochimica Acta, 2009, 97 (4-5), pp.257-260. 10.1524/ract.2009.1607 . cea-01262581

\section{HAL Id: cea-01262581 https://hal-cea.archives-ouvertes.fr/cea-01262581}

Submitted on 26 Jan 2016

HAL is a multi-disciplinary open access archive for the deposit and dissemination of scientific research documents, whether they are published or not. The documents may come from teaching and research institutions in France or abroad, or from public or private research centers.
L'archive ouverte pluridisciplinaire HAL, est destinée au dépôt et à la diffusion de documents scientifiques de niveau recherche, publiés ou non, émanant des établissements d'enseignement et de recherche français ou étrangers, des laboratoires publics ou privés. 


\title{
Plutonium in the environment: key factors related to impact assessment in case of an accidental atmospheric release
}

\author{
By Ph. Guétat ${ }^{1} *$, V. Moulin ${ }^{2}$, P. Reiller ${ }^{2}$, T. Vercouter ${ }^{2}$, L. Bion ${ }^{2}$, P. Fritsch ${ }^{3}$, M. Monfort ${ }^{3}$, A. Flüry-Herard ${ }^{4}$, A. Comte $^{4}$, \\ F. Menetrier ${ }^{4}$, E. Ansoborlo ${ }^{5}$, F. Jourdain ${ }^{6}$, L. Boucher ${ }^{6}$ and F. Vandorpe ${ }^{6}$ \\ ${ }^{1}$ CEA Valduc, 21120 Is-sur-Tille, France \\ 2 CEA Saclay, 91191 Saclay, France \\ 3 CEA DIF, 91680 Bruyères, France \\ ${ }^{4}$ CEA FAR, 92268 Fontenay-aux-Roses, France \\ ${ }^{5}$ CEA Marcoule, 30207 Bagnols-sur-Cèze, France \\ ${ }^{6}$ CEA Cadarache, 13108 St. Paul-lez-Durance, France
}

(Received June 17, 2008; accepted in final form September 23, 2008)

\section{Plutonium / Radiological impact / Airborne particles / Environment / MOX}

Summary. This paper deals with plutonium and key factors related to impact assessment. It is based on recent work performed by CEA which summarize the main features of plutonium behaviour from sources inside installations to the environment and man, and to report current knowledge on the different parameters used in models for environmental and radiological impact assessment. These key factors are illustrated through a case study based on an accidental atmospheric release of $\mathrm{Pu}$ in a nuclear facility.

\section{Introduction}

Plutonium is a raw material of the nuclear industry and exists in a large variety of compounds.

The objective of present work is to illustrate through a case study, the important factors influencing the results of a radiological impact assessment study. This work is based on a recent report performed by CEA [1] which intends to present, discuss and summarize the main features of plutonium behaviour from sources inside installations to the environment and man. Transfer and behaviour in man and effects on health are also presented. The objective of this report is to gather scientific information useful for decision makers in case of accident or for regulation purposes.

The case study selected here is based on an accidental atmospheric release of $\mathrm{Pu}$ in a nuclear facility. The key factors which influence the radiological assessment study is discussed in the following sections.

\section{Case study}

A fire in a glove box containing $1 \mathrm{~kg}$ of heavy metal is considered. A basic safety calculation would consider the emission of $1 \%$ of ${ }^{239} \mathrm{Pu}$, and according to the default option

\footnotetext{
*Author for correspondence (E-mail: philippe.guetat@cea.fr).
}

selected by ICRP for populations [2], in the form of aerosol particles of $1 \mu \mathrm{m}$ diameter with moderate solubility (M).

On this basis, keeping in mind the simplification objective as expressed just before, the exposure at $1 \mathrm{~km}$ from the emission point, for a release of $1 \mathrm{GBq}$ of ${ }^{239} \mathrm{Pu}$ will be of $1 \mathrm{mSv}$ all pathways taken into account [1]. The exposure pathway is for $95 \%$ inhalation, for $4 \%$ ingestion of leaf vegetables and fruits, and for $1 \%$ ingestion of cereals. Exposure to children is less than that to adults and does not imply supplementary protection. For the case under interest, the release of $10 \mathrm{~g}$ of ${ }^{239} \mathrm{Pu}$ would be of $2.3 \times 10^{10} \mathrm{~Bq}$ (or $20 \mathrm{GBq}$ if oxygen mass is taken into account). The exposure at $48 \mathrm{~h}$ would be then above the intervention level of $10 \mathrm{mSv}$ and would imply a confinment of populations. Protective actions relative to food consumption and trade restriction would also be usefull and would concern about the same area.

\section{Nature, isotopic composition and physico-chemical form}

First, it is important to check that the accident deals with a $\mathrm{PuO}_{2}$ powder and not a $\mathrm{MOX}$ powder. Indeed, the ${ }^{239} \mathrm{Pu}$ activity of ten grams of powder would be relatively smaller in the case of a fresh MOX powder containing $11.6 \%$ plutonium in mass (Table 1), that is $1.4 \times 10^{8} \mathrm{~Bq}$ of ${ }^{239} \mathrm{Pu}$ per gram of powder.

Second, if ${ }^{239} \mathrm{Pu}$ is the major isotope in terms of mass, it is not the case in terms of activity. In the case of MOX (Table 1 ), ${ }^{238} \mathrm{Pu}$ activity is about twenty times higher than the activity of ${ }^{239} \mathrm{Pu}$ with an equivalent inhalation dose coefficient. The ${ }^{241} \mathrm{Pu}$ activity ( $\beta$ emitter) is also higher $\left(5 \times 10^{10} \mathrm{~Bq} \mathrm{~g}^{-1}\right.$ of powder $)$ but with an inhalation dose coefficient 50 times lower. An important point is the case of ${ }^{241} \mathrm{Am}$ produced by filiation of ${ }^{241} \mathrm{Pu}$ which must be taken into account.

Hence if we consider Pu isotopy of MOX $11.6 \%$, the sum of activities of alpha emitters (which have relatively close dose coefficients) and also $2 \%$ of ${ }^{241} \mathrm{Pu}$ activity, the toxicity by inhalation of one gram of this plutonium is 15 times higher than that of one gram of pure ${ }^{239} \mathrm{Pu}$. On this point 
Table 1. Isotopic composition of fresh MOX 11.6\% in mass, activity and dose.

\begin{tabular}{lcccccc}
\hline & $\begin{array}{c}\text { Isotopic } \\
\text { composition } \\
\text { in mass }\end{array}$ & $\begin{array}{c}\text { Specific } \\
\text { activity } \\
\mathrm{Bq} / \mathrm{g}\end{array}$ & $\begin{array}{c}\text { Isotopic } \\
\text { composition } \\
\text { in activity }\end{array}$ & $\begin{array}{c}\text { Activity of } \\
1 \mathrm{~g} \text { of Pu }\end{array}$ & $\begin{array}{c}{ }^{239} \mathrm{Pu} \\
\text { equivalence } \\
\text { factor in dose }\end{array}$ & $\begin{array}{c}\text { Relative } \\
\text { contribution } \\
\text { in dose }\end{array}$ \\
\hline Pu238 & $3.6 \%$ & $6.3 \times 10^{11}$ & $5.1 \%$ & $2.3 \times 10^{10}$ & 1 & $20-64 \%$ \\
Pu239 & $50.8 \%$ & $2.3 \times 10^{9}$ & $0.26 \%$ & $1.2 \times 10^{9}$ & 1 & $1-3 \%$ \\
Pu240 & $24.9 \%$ & $8.3 \times 10^{9}$ & $0.46 \%$ & $2.1 \times 10^{9}$ & 1 & $2-6 \%$ \\
Pu241 & $11.2 \%$ & $3.8 \times 10^{12}$ & $94 \%$ & $4.2 \times 10^{11}$ & 0.02 & $7-24 \%$ \\
Am241 & $1.1 \%$ & $1.3 \times 10^{11}$ & $0.33 \%$ & $1.5 \times 10^{9}$ & 0.8 & $1-3 \%$ \\
Pu242 & $8.4 \%$ & $1.5 \times 10^{8}$ & $0.0 \%$ & $1.3 \times 10^{7}$ & 1 & $0-0 \%$ \\
Total & $100 \%$ & & $100 \%$ & $4.5 \times 10^{11}$ & & $31-100 \%$ \\
\hline
\end{tabular}

there is a source of underestimation of the impact which could be important. Generally, the exposure to plutonium is mainly due to 238 and 241 isotopes and then to 239 isotope. The contribution of ${ }^{241} \mathrm{Am}$ is more variable as a function of plutonium age.

The third point concerns the physico-chemical form and the corresponding solubility (moderate $\mathrm{M}$ or slow $\mathrm{S}$ ). The ratio between the $\mathrm{S}$ form for the dioxide and the $\mathrm{M}$ form taken by default varies between 3 and 5 according to the isotopes. An overestimation could then be made which could be avoided.

\section{Granulometry}

The last point concerns the size of released particles. This aspect is particularly important since it appears at different levels in the calculation. This parameter could also be related to the physico-chemical form.

Firstly, the particle size is involved in the resuspension process. In our example, a fire with destruction of the glove box could lead to a resuspension of $5 \times 10^{-3}$ of the powder activity (relatively close of the $1 \%$ used just above). But the inhalable fraction would be only about $10 \%$ of the resuspension and would induce an exposure by inhalation at least 10 times lower. It is interesting to note that this phenomena is even more important for nitrate or fluoride forms for which an inhalable fraction of $0.1 \%$ is recommended notably by DOE [3].

Granulometry is also concerned in the filtration step. The filter efficiency is certainly higher for larger particles. The use of a factor of $10^{-3}$ in safety reports is probably the source of considerable overestimation. We will pursue nevertheless our example by considering the absence or inefficiency of filtration system.

We consider generally a particle population with a heterogeneous dimension and with a distribution following a log-normal law. Three main parameters are involved, namely the density of the particles, the median aerodynamic diameter in activity and the geometric standard deviation of the distribution. Fig. 1 presents one example of particle distribution for a density of $11.4 \mathrm{~kg} \mathrm{~L}^{-1}$. Important points to know are on one hand the quantity unit, namely particles number in mass or activity, on the other hand the kind of diameter, namely physical diameter (sphere equivalent volume) or aerodynamic diameter. There is here an important source of errors.

The aerodynamic diameter varies as the square root of the density. The density used by ICRP for all industrial com-

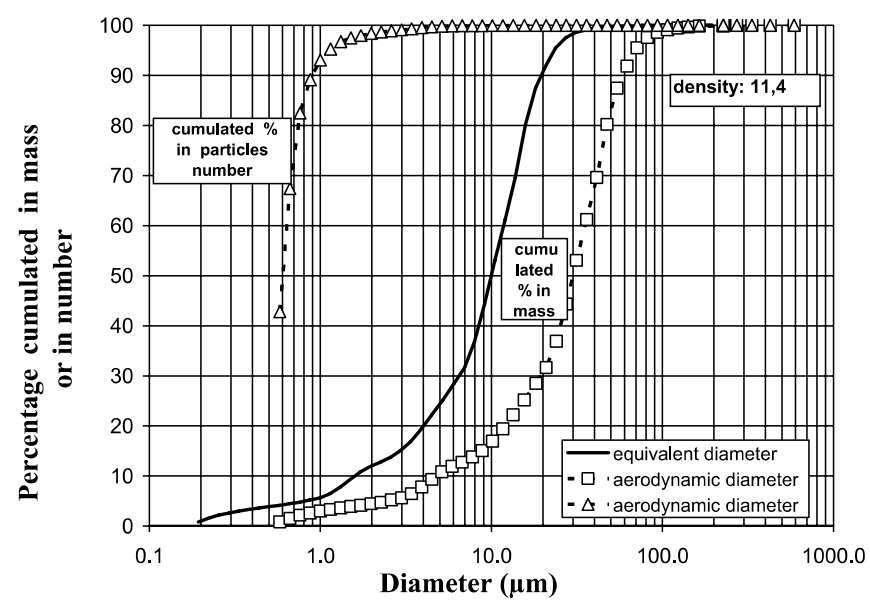

Fig. 1. Particles' distribution vs. diameter.

pounds is $3 \mathrm{~kg} \mathrm{~L}^{-1}$. The theoretical density of plutonium oxide being $11.5 \mathrm{~kg} \mathrm{~L}^{-1}$, there could be an underestimation of the particle aerodynamic diameter by a factor of 2 , which would then slightly modify the inhalable part. For the distribution presented in Fig. 1, 15\% of the particles have a diameter $<10 \mu \mathrm{m}$. This situation is relatively close to the present case study.

The particle size also affects the atmospheric concentration as a function of the distance (or transfer time) due to particle deposition. Considering day unstable meteorological conditions, a release at $20 \mathrm{~m}$ of height with a low wind velocity of $1 \mathrm{~m} / \mathrm{s}$, particles having a diameter higher than $100 \mu \mathrm{m}$ will then be deposited in the first $2 \mathrm{~km}$, and the inhalable aerosols part varies from $15 \%$ at origin to $60 \%$ at $30 \mathrm{~km}$ of distance [1].

Fig. 2 shows the variation of the mean dose coefficient with the distance taking into account the granulometry evolution for different meteorological conditions, characterized by the stability conditions $(\mathrm{St}=$ stable, $\mathrm{Un}=$ unstable $)$ and the wind velocity. This factor increases with the distance downwind since small particles become predominant. The curves shapes can be explained as follow. First, there is a conjugation of the $\mathrm{S}$ physico-chemical form selected and the important fraction (in activity) of size particle class $(10 \mu \mathrm{m})$ in the content of inhalable particles. This leads to a mean dose factor five times lower. The second point is the importance at short distance of non inhalable particles. The separation of particles is performed more or less quickly according to the meteorological conditions. It should be noticed that the dose factor at short distance is 25 times less than the standard dose per unit intake coefficient (DPUI). 


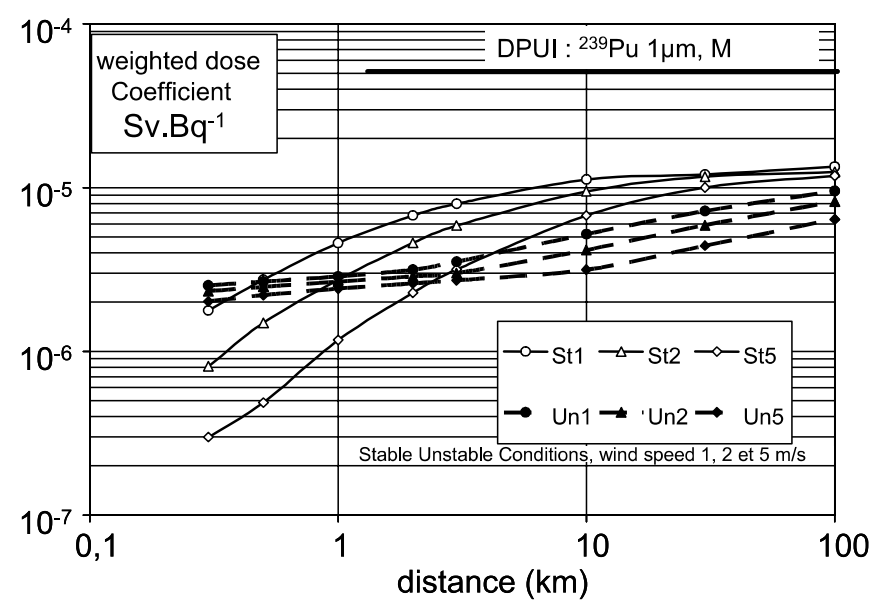

Fig. 2. Effect of granulometry on dose coefficient as a function of the distance.

\section{Contamination of vegetal and animal productions}

The previous analysis show that the granulometry has a multiple influence on the main exposure, namely the inhalation. The exposure is then principally dependant of the activity fraction released as inhalable form. According to the inhalation pathway, particles with a diameter higher than $10 \mu \mathrm{m}$ could be neglected. But the importance of captation of bigger particles (with a diameter higher than 10 or $100 \mu \mathrm{m}$ ) for the food pathway has to be studied. Indeed, the deposition velocity on ground $\left(5 \times 10^{-3} \mathrm{~m} / \mathrm{s}\right)$ for inhalable particles is multiplied by a factor 20 for particles of $70 \mu \mathrm{m}$, and by a factor of 200 for particles of 200-300 $\mu \mathrm{m}$ (aereodynamic diameter). Ingestion then becomes the main pathway even with a dose factor lower that the inhalation dose factor.

Concerning the air-vegetable transfer factors and the biological decrease of deposit on vegetables [4], it appears that captation is lower for particles of some hundred $\mu \mathrm{m}$ than for inhalable particles by a factor of around 3. Captation is negligeable for higher size particles. Granulometry is not a key factor for deposit captation by rain water. The losses of foliar deposit of aerosols are relatively rapid during the first days without insofar as being important. They are limited to a factor 2 or 3 of reduction after 10 to $15 \mathrm{~d}$ and then remain stable. Afterward, only the plant growth still reduces the concentration of edible parts.

The calculation described in [1] with a granulometry of $1 \mu \mathrm{m}$ (and a sedimentation rate of $5 \times 10^{-3} \mathrm{~m} / \mathrm{s}$ ) shows that the food trade limit could be overtaken up to a distance of $1 \mathrm{~km}$ for a release of around $1 \mathrm{~g}$ of ${ }^{239} \mathrm{Pu}$ or also around $3 \mathrm{GBq}$ of ${ }^{239} \mathrm{Pu}$. In our example the equivalent mass activity is 15 times higher. Moreover considering that (i) the $\mathrm{Pu}$ mass released is $5 \mathrm{~g}$, (ii) the mean deposit rate at $1 \mathrm{~km}$ is $5 \times 10^{-2} \mathrm{~m} / \mathrm{s}$ and (iii) the vegetable captation is 3 times less, the trade limit would be exceeded by a factor of 200 which then increases the intervention area up to a distance of around $10 \mathrm{~km}$.

The other exposure pathways are minor because plutonium is a non-metabolized element. There is no significant transfer from soil, no transfer between leaves and fruits or roots, and transfers to animal products (meat and milk) are relatively low. The resuspension of soil particle has been in the past considered to be a significant pathway. Analysis of
Chernobyl accident, however, has shown that this is of minor importance.

The above analyses of the scenario lead to a better understanding of what could be the reality and the needs of intervention in case of an accident:

- First of all, the toxicity of one gram of plutonium largely depends on its isotopy. In the retained example, it is 15 times higher to one gram of pure ${ }^{239} \mathrm{Pu}$.

- Secondly, the granulometry of released particles plays a major role in the relative importance of the different exposure ways. For a release of fine particles (reference case since there is a filtration level), inhalation is the dominant exposure pathway. However, in the absence of filtration, the release could be higher with particles of greater sizes. The ingestion pathway may then become the most important. Under the conditions in our example, the inhalation exposure would remain less than $10 \mathrm{mSv}$ in the early phase of the accident, out of the center, and would not imply confinement measures. But the food restriction intervention in the later phase, for leaf vegetables, would concerns an area of $10 \mathrm{~km}$ length.

- Thirdly, in both cases (with or without filtration), the consequences of an accidental $\mathrm{Pu}$ release are limited in time, the pathways playing a role at long term being secondary.

- Finally, results are insensitive to age and intervention measures should be applied (or not) to the whole population. The fetus transfer or through maternal milk transfer are also relatively low.

\section{Relative aspects to exposure and risks}

These points are rarely discussed in impact studies. The dose coefficients (dose per unit intake) are calculated in a standard way with a density of $3 \mathrm{~kg} \mathrm{~L}^{-1}$ and a standard

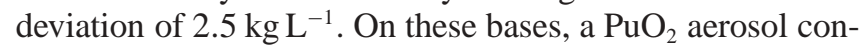
tains 420 particles per $\mathrm{Bq}$ [5]. In reality, the density is near to $9 \mathrm{~kg} \mathrm{~L}^{-1}$ and the standard deviation to $1.7 \mathrm{~kg} \mathrm{~L}^{-1}$. Under these conditions the particle number would be much lower, around 30 particles per Bq. Uncertainties on these dose factors increase linearly with the diminution of particle number.

It is interesting to notice that uncertainties on effective doses delivered to the population are low. On the contrary, they are much higher at the individual scale and insofar as the particle number is small.

Concerning the uncertainties on the risk, the spatial dose distribution could be very heterogeneous. The studies show that the presence of hot spots is systematically associated to the appearance of fibroses sources, which decreases the delivered doses to cell targets. Hence in the case of insoluble compounds of high specific activity, calculated equivalent doses according to the ICRP recommendations would be highly overestimated if they are assumed to reflect the cancer risk.

\section{Conclusions}

This study performed on the basis of a complete report [1] confirms information brought by [6] for respirable aerosols for fresh MOX powders. Nevertheless it shows that, at least 
in some cases, when measured parameters are used, the impact of an accident could be very different from what is described by standard theoretical assessments. Details on the nature of plutonium handled in the facility, its isotopy and granulometry (in case of powders) must be known by the nuclear operators to accurately assess the impact. It is worth noting that because of the safety arrangements related to criticality risk, the inventories that could be concerned in a laboratory are necessarily limited.

\section{References}

1. Guetat, Ph., Monfort, M., Ansoborlo, E., Bion, L., Boucher, L., Jourdain, F., Moulin, V., Reiller, P., Vandorpe, F., Vercouter, T., Comte, A., Flüry-Herard, A., Fritsch, P., Menetrier, F.: Plutonium in the environment - Bibliographic study and quantification. Rapport CEA R-6186 (2008).
2. ICPR: The ICRP database of dose coefficients. Age-dependant doses to the members of the public from intake of radionuclides. ICRP Publication 71, Part 4: Inhalation Dose Coefficients. Pergamon Press, Oxford (1996).

3. DOE: Airborne release fractions/rates and respirable fractions for nonreactor nuclear facilities. Analysis of Experimental Data. DOE HDBK 3010 94, Vol. I, U.S. Department of Energy, Washington DC, 20585, December (1994), 359 p.

4. Pröhl, G., Hoffman, P. O.: Modelling of radionuclide interception and loss processes in vegetation and of transfer in semi-natural ecosystems. Second report of the VAMP Terrestrial Working Group (1992). IAEA - TECDOC 857 (1996).

5. Fritsch, P.: Uncertainties in doses due to the number of aerosol particles: study on ${ }^{239} \mathrm{PuO}_{2}$ using default parameters for workers. Health Phys. 87, 416-422 (2004).

6. Magill, J., Hamilton, D. Lützenkirchen, K., Tufan, M., Tamborini, G., Wagner, W., Berthou, V., von Zweidorf, A.: Consequences of a radiological dispersal event with nuclear and radioactive sources. Sci. Glob. Secur. 15, 107-132 (2007). 